\title{
Description of Culicoides pseudoheliconiae sp.n. from Peruvian Amazon and revalidation of Culicoides contubernalis Ortiz \& Leon (Diptera: Ceratopogonidae)
}

\author{
Maria Luiza Felippe-Bauer $/{ }^{+}$, Abraham G Cáceres ${ }^{1}$, Cristiane S Silva, \\ William Valderrama-Bazan², Antero Gonzales-Perez ${ }^{3}$, Janira M Costa ${ }^{4}$
}

Laboratório de Diptera, Instituto Oswaldo Cruz-Fiocruz, Av. Brasil 4365, 21045-900 Rio de Janeiro, RJ, Brasil 'División de Entomologia, Instituto Nacional de Salud, Ministério de Salud and Instituto de Medicina Tropical Daniel A. Carrión, Universidad Nacional Mayor de San Marcos, Lima, Peru ${ }^{2}$ Servicio Nacional de Sanidad Agraria, Ministério de Agricultura, Lima, Peru ${ }^{3}$ Centro de Salud Bagua Grande, Sub Región de Salud Bagua, Amazonas, Peru ${ }^{4}$ Departamento de Entomologia, Museu Nacional, Universidade Federal do Rio de Janeiro, Rio de Janeiro, RJ, Brasil

A new species of the Culicoides hylas species group, Culicoides pseudoheliconiae Felippe-Bauer is described and illustrated based on female specimens from Peruvian Amazon, and Culicoides contubernalis Ortiz \& Leon from Ecuador is resurrected and redescribed as a valid species. A systematic key, table with numerical characters of females of species of the Culicoides hylas group are given.

Key words: Culicoides hylas group - C. pseudoheliconiae sp.n. - C. contubernalis - Neotropical bloodsucking midges Peruvian Amazon - Ecuador

Ortiz and Leon (1954) described Culicoides contubernalis as a variety of Culicoides rozeboomi Barbosa from two females collected in San Miguel de Los Colorados, Ecuador, focused primarily on the differences on the pale spots of the legs. Wirth and Blanton (1956) based on original description, considered C. contubernalis as junior synonym of Culicoides verecundus Macfie. This synonymy was accepted in several subsequent publications by Forattini (1957), Wirth and Blanton $(1959,1968)$, Wirth et al. (1988), Borkent and Wirth (1997), Borkent and Spinelli (2000).

During an entomological survey in Departments of Madre de Dios and San Martin, Peru, four specimens of Culicoides were collected by CDC light trap. These specimens belonging to the hylas species group of the subgenus Hoffmania Fox were given to the first author for determination. Two specimens belong to an undescribed species of this species group are described herein. The other two, are very similar to one female specimen deposited in the Ceratopogonidae Collection's of Laboratório de Diptera of Instituto Oswaldo Cruz (IOC) and determined by Willis Wirth as C. verecundus Macfie. This slide mounted specimen was collected by Luis A Leon in San Miguel de Los Colorados, Ecuador, type locality of $C$. contubernalis. We could observe that the specimens from Ecuador and Peru differ from C. verecundus in the aspect of the pale wing spots and

\footnotetext{
+ Corresponding author: mlfbauer@ioc.fiocruz.br
} Received 29 November 2007

Accepted 12 March 2008 length of the proboscis. Unfortunately, we could not examine the type material of $C$. contubernalis deposited at Universidad Central de Quito. Based on the original description of $C$. contubernalis, we can conclude that the assumption of Wirth and Blanton (1956) was erroneous and therefore, $C$. verecundus and C. contubernalis must be considered as two distinct species.

The purpose of this work is to describe and illustrate one new species of the $C$. hylas species group, redescribe C. contubernalis and provide a key for the identification of species of this group.

The general terminology used is that employed in $\mathrm{Cu}$ licoides papers by Wirth and Blanton $(1959,1973,1974)$ for Panama, the Amazon Basin, and the West Indies, and the atlas of wing photographs of Neotropical species by Wirth et al. (1988). The terms of wing veins follow the system of the Manual of Neartic Diptera (Mac Alpine et al. 1981), with modifications proposed by Szadziewski (1996). A revision of the neotropical biting midges of the C. hylas species group and its distribution can be found in Wirth and Blanton (1968) and in Borkent and Spinelli (2000). All measurements are in micrometers, except those of the wings which are in millimeters.

\section{KEY TO THE SPECIES OF THE CULICOIDES HYLAS GROUP}

1. Wing markings diffuse, pale spots not brightly contrasting; pale spot that crosses the second radial cell subdivided in two separate spots (Figs 1-2) .. pseudoheliconiae sp.n. Felippe-Bauer

Wing with contrasting pattern of dark and pale spots; pale spot that crosses the second radial cell, single (Fig. 7)

2. Hind femur dark to tip 3

Hind femur with subapical pale band 5

3. Mid femur with subapical pale band (mid knee dark); 
3rd palpal segment with irregular sensory pit

hylas Macfie

Mid femur with apical pale band (mid knee pale); 3rd palpal segment without sensory pit, the sensoria scattered on surface of 3 rd segment .. 4

4. Apices of veins M1, M2, $\mathrm{CuA}_{1}$ and $\mathrm{CuA}_{2}$ pale.......... heliconiae Fox \& Hoffman

Apices of veins $\mathrm{M} 1$ and $\mathrm{M} 2$ pale, $\mathrm{CuA}_{1}$ and $\mathrm{CuA}_{2}$ dark .. palpalis Macfie

5. Pale spot absent in front of base of vein M1; flagellomeres 2-8 with prominent four or five-branched hyaline sensory filaments ....... xanifer Wirth \& Blanton

Pale spot present in front of base of vein M1, flagellomeres 2-8 with simple hyaline sensory filament ......................... 6

6. Apices of veins $\mathrm{M} 1, \mathrm{M} 2, \mathrm{CuA}_{1}$ and $\mathrm{CuA}_{2}$ pale ..... 7 dark

Apices of veins $\mathrm{M} 1$ and $\mathrm{M} 2$ pale, $\mathrm{CuA}_{1}$ and $\mathrm{CuA}_{2}$

7. Greater species, with wing length $1.50 \mathrm{~mm}$, P.R. 6.0, A.R. 1.26, $\mathrm{P} / \mathrm{H}$ ratio 1.38 ............. aitkeni Wirth \& Blanton

Smaller species, wing length $1.30-1.35 \mathrm{~mm}$, P.R. 3.8-4.3, A.R. 1.09-1.14, $\mathrm{P} / \mathrm{H}$ ratio 1.14-1.18 contubernalis Ortiz \& Leon

8. Mid knee dark polypori Wirth \& Blanton

Mid knee pale verecundus Macfie

\section{C. pseudoheliconiae Felippe-Bauer, sp.n. (Figs 1-6)}

Diagnosis - This new species can be easily distinguished from the other species of the $C$. hylas group by the diffuse pale spots in the wing and by the presence of double pale spot which crosses the second radial cell reaching cell $\mathrm{r}_{3}$. Male unknown.

Female - Wing length 1.22-1.27 $(1.25, \mathrm{n}=2) \mathrm{mm}$; breadth $0.54-0.59(0.57, \mathrm{n}=2) \mathrm{mm}$.

Head - Brown. Eyes contiguous, bare. Flagellum (Fig. 3) brown, with base of flagellomeres 1-8 conspicuously pale; flagelomeres with mean lengths of 53-4545-45-45-45-45-48-59-64-72-80-112 $\mu \mathrm{m}(\mathrm{n}=2)$; antennal ratio 1.01-1.03 $(1.02, \mathrm{n}=2)$; sensilla coeloconia on flagellomeres 1, 9-13. Palpus (Fig. 5) brown; lengths of segments 27-77- 96-45-32 $\mu \mathrm{m}(\mathrm{n}=2)$; 3rd segment slender, subcylindrical, without sensory pit, with scattered sensoria; palpal ratio 3.7-4.3 $(4.0, \mathrm{n}=2)$. Proboscis moderately long, $\mathrm{P} / \mathrm{H}$ ratio $1.08-1.09(1.08, \mathrm{n}=2)$; mandible with 19-21 teeth.

Thorax - Brown, without definite pattern in slide mounted specimens. Legs mostly brown; fore and mid femora, respectively, with subapical and apical pale bands, hind femur entirely dark; mid knee pale; fore and hind tibiae with subbasal and mid tibia with basal pale band; hind tibia pale apically (Fig. 4); hind tibial comb with six spines, the second from de spur longest. Tarsi pale, first tarsomere darkest. Wing (Figs 1-2) with pattern typical of C. hylas group: one round pale spot over the 2 nd radial cell; three spots on cell $\mathrm{r}_{3}$ : one in front of base of vein $\mathrm{M}_{1}$, extending over vein into cell $\mathrm{m}_{1}$, another just below the pale spot on 2nd radial cell, not reach-
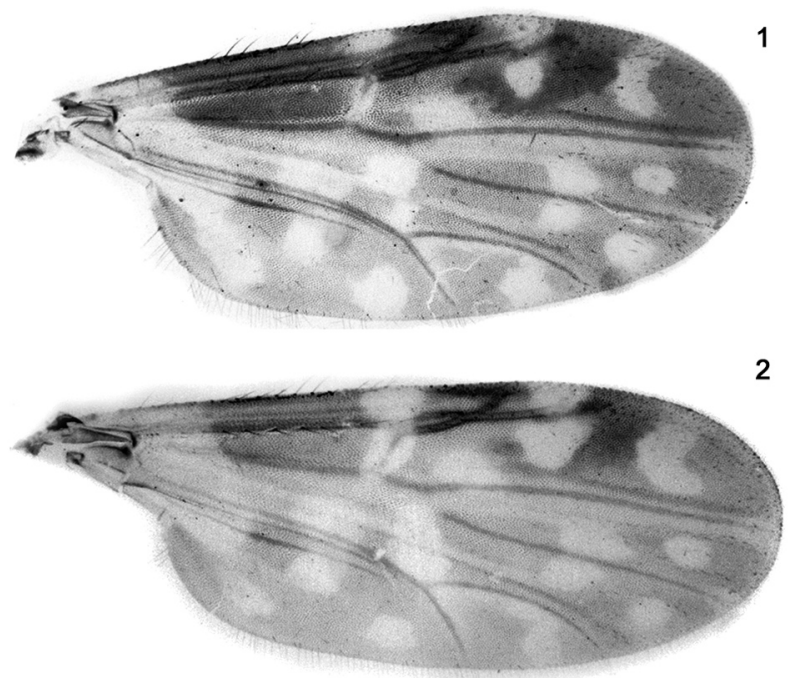

Figs 1-2: variation in the wing pattern of Culicoides pseudoheliconiae sp.n.

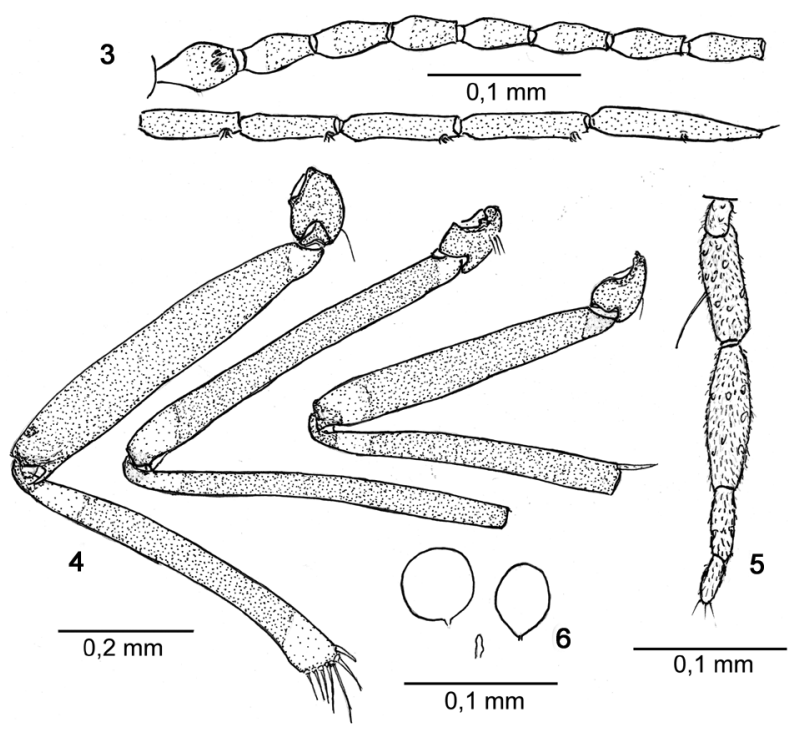

Figs 3-6: Culicoides pseudoheliconiae sp.n., female. 3: antenna; 4: legs (left to right) hind, mid, and fore; 5: palpus; 6: spermathecae.

ing vein $\mathrm{M}_{1}$ and one distal and narrow pale spot; a pale spot over $\mathrm{r}-\mathrm{m}$ crossvein extending from vein $\mathrm{M}$ to costal margin, narrow, slender and subdivided in one specimen (Fig. 1) or entire in an other (Fig. 2); cell $\mathrm{m}_{1}$ with two rounded pales spots, the distal one smaller and far from wing margin; cell $\mathrm{m}_{2}$ with five pale spots, one in proximal part of cell, double pale spot lying between medial, mediocubital forks, one rounded, subapical and another in distal portion near wing margin; cell cua with a rounded pale spot reaching wing margin and continued proximad along vein $\mathrm{CuA}_{1}$ reaching base of fork; anal cell with two well separated pale spots on distal portion, one anterior of mediocubital fork and the other reaching wing margin (Fig. 1) or near wing margin (Fig. 2); base of the wing greatly pale since the costal vein to anal cell; apices of veins $\mathrm{M}_{1}$ and $\mathrm{M}_{2}$ pale, $\mathrm{CuA}_{1}$ and $\mathrm{CuA}_{2}$ dark; costal ratio $0.67-0.70(0.69, \mathrm{n}=2)$. 


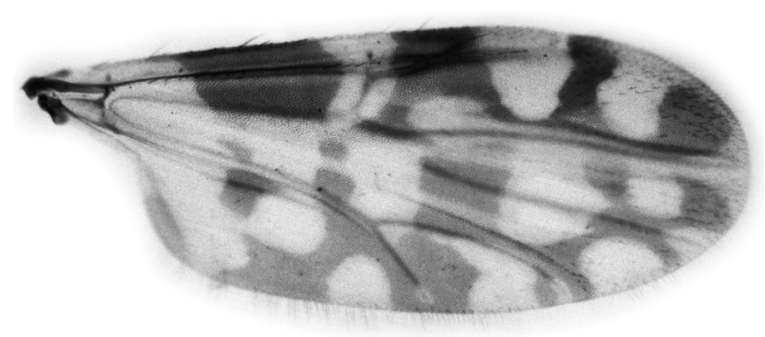

Fig. 7: Culicoides contubernalis Ortiz \& Leon, female. Wing photograph
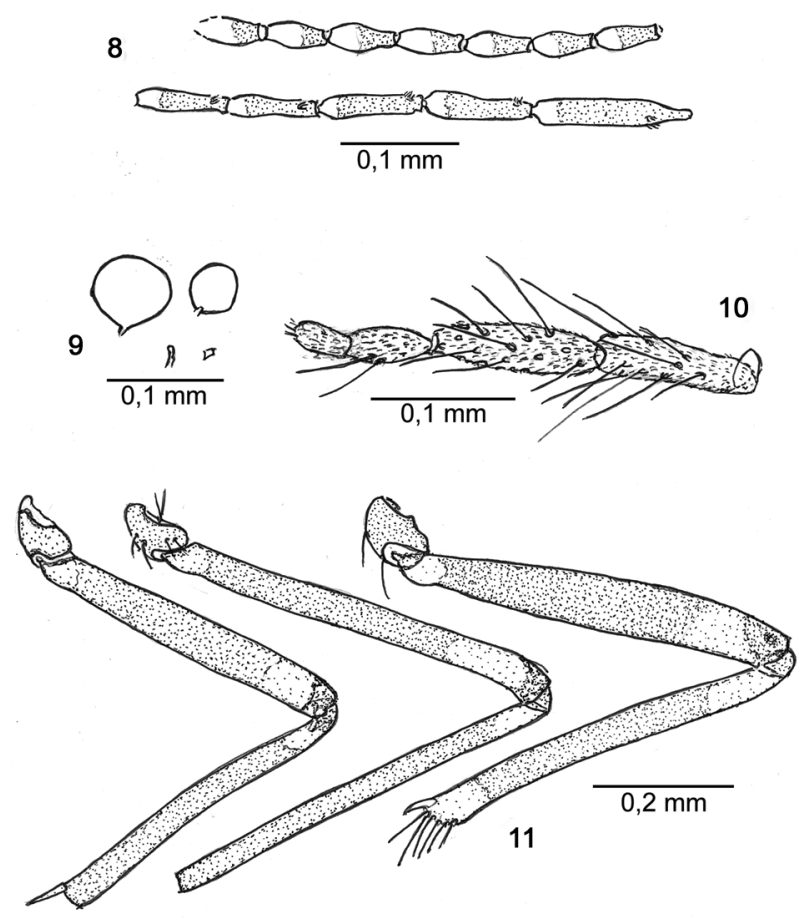

Figs. 8-11: Culicoides contubernalis Ortiz \& Leon, female. 8: antenna; 9: spermathecae; 10: palpus; 11: legs (left to right) fore, mid, and hind.

Abdomen - Brown. Two unequal sized ovoid spermathecae (Fig. 6) with very short, slender necks, measuring $59-64(62, \mathrm{n}=2)$ by $45-48(47, \mathrm{n}=2) \mu \mathrm{m}$ and $43-53(48, \mathrm{n}=2)$ by $32-37(35, \mathrm{n}=2) \mu \mathrm{m}$, respectively. Rudimentary third spermathecae present.

Male - Unknown.

\section{Distribution - Peru (Madre Dios, San Martin).}

Types - Holotype female (Dip.Cer. 448), El Porvenir, Distrito de Juan Guerra, Provincia de San Martin, Departamento de San Martin, PERU, 24.II.2001, CDC light trap. Paratype female (Dip.Cer. 449), Santa Rosa (12\%42’11'S 69³3'14'W), Distrito de Laberinto, Provincia de Tambopata, Departamento de Madre de Dios, PERU, 08.VIII.2002, CDC light trap. Deposited in Ceratopogonidae Collection of Diptera Laboratory, Instituto Oswaldo Cruz (IOC), Rio de Janeiro, Brazil.

Etymology - The name of this species is based on its close similarity in the wing pattern with $C$. heliconiae.
Discussion - C. pseudoheliconiae sp.n. is a typical member of the subgenus Hoffmania and most closely resembles C. heliconiae, C. hylas and C. palpalis by the entirely dark hind femur. Regarding the peculiar aspect of the wing it is most similar to C. heliconiae from which can be distinguished by the absence of pale spots on apices of veins $\mathrm{CuA}_{1}$ and $\mathrm{CuA}_{2}$, by the smaller size 1.22-1.27 mm (1.29-1.69 $\mathrm{mm}$ in C. heliconiae) and $\mathrm{P} / \mathrm{H}$ ratio 1.08-1.09 (1.33 in C. heliconiae). Also it can be distinguished from all species of the $C$. hylas group by characteristics outlined in the key.

\section{C. contubernalis Ortiz \& Leon, redescription and reval- idation (Figs 7-11)}

C. contubernalis var. of rozeboomi Ortiz and Leon (1954): 574 (female; Ecuador; figs antennae, palpus, spermathecae, wing).

C. verecundus Wirth and Blanton (1956): 98 (syn. of C. contubernalis var. of rozeboomi); Forattini (1957): 249 (in neotropical catalog; in part, Ecuador records); Wirth and Blanton (1959): 278 (in part, Ecuador records); Wirth and Blanton (1968): 209 (in part, Ecuador records); Wirth et al. (1988): 20 (in Atlas; in part, Ecuador records); Borkent and Wirth (1997): 85 (in catalog; syn. of C. contubernalis var. of rozeboomi); Borkent and Spinelli (2000): 35 (in catalog, syn. of $C$. contubernalis var. of rozeboomi); Borkent and Spinelli (2007): 69 (in catalog, syn. of C. contubernalis var. of rozeboomi).

Diagnosis - This species of the $C$. hylas species group is distinguished by the following combination of characters: mid and hind femur with subapical pale band (mid knee dark); apices of veins $\mathrm{M}_{1}, \mathrm{M}_{2}, \mathrm{CuA}_{1}$ and $\mathrm{CuA}_{2}$ pale and wing pattern most similar to verecundus. Male unknown.

Female - Wing length $1.30-1.35(1.32, \mathrm{n}=3) \mathrm{mm}$; breadth $0.57-0.59(0.57, \mathrm{n}=3) \mathrm{mm}$.

Head - Brown. Eyes contiguous, bare. Flagellum (Fig. 8) brown with base of segments conspicuously pale; flagelomeres with mean lengths of 63-52-50-48-51-5049-51-78-78-85-89-128 $\mu \mathrm{m}(\mathrm{n}=3)$; antennal ratio 1.09$1.14(1.11, \mathrm{n}=3)$; sensilla coeloconia on flagellomeres 1 , 9-13. Palpus (Fig. 10) brown; lengths of segments 27-92119-55-41 $\mu \mathrm{m}(\mathrm{n}=3)$; 3rd segment slender, subcylindrical, without sensory pit, with scattered sensoria; palpal ratio 3.8-4.3 (4.1, $\mathrm{n}=3)$. Proboscis moderately long, $\mathrm{P} / \mathrm{H}$ ratio 1.14-1.18 $(1.15, \mathrm{n}=3)$; mandible with 20-23 teeth.

Thorax - Brown, without definite pattern in slide mounted specimens. Legs mostly brown; fore, mid and hind femora with subapical, tibiae with subbasal pale bands; mid knee dark; hind tibia pale apically (Fig. 11); hind tibial comb with six spines, the second from de spur longest. Tarsi pale, first tarsomere darkest. Wing (Fig. 7) with pattern typical of $C$. hylas group: cell $\mathrm{r}_{3}$ with three spots, one in front of base of vein $M_{1}$, extending over vein into cell $\mathrm{m}_{1}$, a pale spot which crosses the second radial cell, single and large, not reaching vein $M_{1}$ and one distal pale spot broadly meeting wing margin; a pale spot over r-m crossvein extending from costal margin to cell $\mathrm{m}_{2}$; cell $\mathrm{m}_{1}$ with two rounded pales spots, the distal one smaller and far from wing margin; cell $\mathrm{m}_{2}$ with five 
TABLE

Numerical characters of females of the Culicoides hylas group

\begin{tabular}{|c|c|c|c|c|c|}
\hline Species & Wing length (mm) & Costal ratio & Antennal ratio & Palpal ratio & $\mathrm{P} / \mathrm{H}$ ratio \\
\hline C. aitkeni & 1.50 & 0.70 & 1.26 & 6.0 & 1.38 \\
\hline C. heliconiae & $1.29-1.69$ & $0.66-0.75$ & $0.99-1.12$ & $3.1-4.6$ & 1.33 \\
\hline C. hylas & $0.99-1.29$ & $0.67-0.72$ & $1.03-1.16$ & $2.7-4.0$ & 1.15 \\
\hline C. contubernalis & $1.30-1.35$ & $0.66-0.69$ & $1.09-1.14$ & $3.8-4.3$ & $1.14-1.18$ \\
\hline C. palpalis & $1.38-1.59$ & $0.65-0.74$ & $1.07-1.20$ & $4.2-6.0$ & 1.32 \\
\hline C. polypori & $1.25-1.59$ & $0.68-0.72$ & $1.09-1.28$ & $3.4-5.6$ & 1.20 \\
\hline C. pseudoheliconiae sp.n. & $1.22-1.27$ & $0.67-0.70$ & $1.01-1.03$ & $3.7-4.3$ & $1.08-1.09$ \\
\hline C. verecundus & $1.35-1.56$ & $0.65-0.72$ & $1.01-1.09$ & $4.6-5.9$ & 1.40 \\
\hline C. xanifer & $1.29-1.50$ & $0.66-0.72$ & $0.97-1.06$ & $4.0-6.0$ & 1.25 \\
\hline
\end{tabular}

pale spots, one in proximal part of cell, double pale spot lying between medial, mediocubital forks, one rounded and subapical and other in distal portion reaching wing margin; cell cua with $_{1}$ a rounded pale spot reaching wing margin and continued proximad along vein $\mathrm{CuA}_{1}$, not reaching base of fork; anal cell with two well separated pale spots on distal portion, one anterior of mediocubital fork and the other reaching wing margin; base of the wing greatly pale since the costal vein to anal cell; apices of veins $\mathrm{M}_{1}, \mathrm{M}_{2}$, pale and $\mathrm{CuA}_{1}$ and $\mathrm{CuA}_{2}$ slightly pale; costal ratio 0.66-0.69 $(0.68, \mathrm{n}=3)$.

Abdomen - Brown. Two unequal sized ovoid spermathecae (Fig. 9) with very short, slender necks, measuring 56-59 $(57, \mathrm{n}=2)$ by $48-59(54, \mathrm{n}=2) \mu \mathrm{m}$ and $43-45$ (44, $\mathrm{n}=3)$ by $37-43(39, \mathrm{n}=3) \mu \mathrm{m}$, respectively. Rudimentary third spermathecae and sclerotized ring present.

Male - Unknown.

Distribution - Ecuador (Pichincha); Peru (Madre de Dios).

Specimens examined - 1 female, Santo Domingo de los Colorados, Provincia de Pichincha, ECUADOR, I. 1956, LA Leon col.; 2 females, Santa Rosa (1242'11" S 69'33'14' W), Distrito de Laberinto, Provincia de Tambopata, Departamento de Madre de Dios, PERU, 08.VIII.2002, CDC light trap. Specimens deposited as voucher material in Ceratopogonidae Collection's of Diptera Laboratory, IOC, Rio de Janeiro, Brazil.

Discussion - C. contubernalis is a typical member of the subgenus Hoffmania and, as outlined in the key, table and in the description, can be distinguished from the other species of the $C$. hylas group by its medium size, aspect of the pale spots of the wing, mid and hind femur with subapical pale band, apices of veins $\mathrm{M}_{1}, \mathrm{M}_{2}, \mathrm{Cu} \mathrm{A}_{1}$ and $\mathrm{CuA}_{2}$ pale, P.R. 4.1, P/H ratio 1.15 and A.R.1.11.

\section{ACKNOWLEDGEMENTS}

To Laboratorio Referencial de la Direccion de Salud Madre de Dios, for personal support in field works. To Rodrigo Mexas and Bruno Eschenazi, for assistance in the wing photographs and plates of figures.

\section{REFERENCES}

Borkent A, Spinelli GR 2000. Catalog of the new work biting midges south of the United States of America (Diptera: Ceratopogonidae). Contr Ent Inter 4: 1-107.

Borkent A, Spinelli GR 2007. Neotropical Ceratopogonidae (Diptera: Insecta). In J Adis, JR Arias, G Rueda-Delgado, KM Wantzen, Aquatic biodiversity in Latin America, Vol. IV, Pensoft, SofiaMoscow, 198 pp.

Borkent A, Wirth WW 1997. World species of biting midges (Diptera: Ceratopogonidae). Bull Am Mus Nat Hist 233: 1-257.

Forattini OP 1957. Culicoides da região neotropical (Diptera: Ceratopogonidae). Arq Fac Hig Saude Publica 11: 161-526.

MacAlpine JF, Peterson BV, Shewell GE, Teskey HJ, Vockeroth JR, Wood DM (eds) 1981. Manual of Neartic Diptera, Vol. I, Monograph 27, Research Branch Agriculture Canada, Ottawa, 674 pp.

Ortiz I, Leon LA 1954. Los Culicoides (Diptera: Ceratopogonidae) de la República del Ecuador. Bol Inf Cient Nac 7: 564-590.

Szadziewski R 1996. Biting midges from Lower Cretaceous amber of Lebanon and Upper Cretaceous Siberian amber of Taimyr (Diptera: Ceratopogonidae). Stud Dipterol 3: 23-86.

Wirth WW, Blanton FS 1956. Studies in Panama Culicoides (Diptera: Heleidae). VI: The hylas group of the subgenus Hoffmania. J Wash Acad Sci 46: 95-99.

Wirth WW, Blanton FS 1959. Biting midges of the genus Culicoides from Panama (Diptera: Heleidae). Proc US Nat Mus 109: 237-482.

Wirth WW, Blanton FS 1968. A revision of the neotropical biting midges of the hylas group of Culicoides (Diptera: Ceratopogonidae). Fla Entomol 51: 201-215.

Wirth WW, Blanton FS 1973. A review of the maruins or biting midges of the genus Culicoides (Diptera: Ceratopogonidae) in the Amazon Basin. Amazoniana 4: 405-470.

Wirth WW, Blanton FS 1974. The West Indian sandflies of the genus Culicoides (Diptera: Ceratopogonidae). US Dept Agr Tech Bull 1474: 1-98.

Wirth WW, Dyce AL, Spinelli GR 1988. An atlas of wing photographs, with a summary of the numerical characters of the Neotropical species of Culicoides (Diptera: Ceratopogonidae). Contr Am Entomol Inst 25: 1-72. 